\title{
EFFECTS OF UNION ORGANIZATION ON STRIKE INCIDENCE IN EU COMPANIES
}

\author{
GIEDO JANSEN*
}

\begin{abstract}
The author reinvestigates the relationship between the organizational power of trade unions and strikes based on data from the European Company Survey 2009 (ECS-2009) and the Institutional Characteristics of Trade Unions, Wage Setting, State Intervention and Social Pacts (ICTWSS) database, which include more than 5,000 firms across all 27 European Union (EU) member states. He shows that the incidence of strikes is higher in companies for which workplace union membership is high, the number of workplace unions is high, and unions dominate establishment-level works councils. These factors interact to affect strike incidence. In addition, the company-level effects of union organization on strike incidence vary across countries. These country differences can partially be explained by differences in national trade union systems, such as decentralization and membership density.
\end{abstract}

$\mathrm{T}$ The presence of trade unions is generally considered a prerequisite for labor strikes; without organization, people lack the ability for collective action to address their grievances (Snyder 1975; Franzosi 1989). The association between union organization and strike incidence is well documented in the literature (e.g., Ross and Irwin 1951; Shorter and Tilly 1974; Snyder 1975; Edwards 1978; Kaufman 1982; Wheeler 1984; Shalev 1992; Tsebelis and Lange 1995; Piazza 2005). Most empirical studies on this matter are based on observations at a national level. Over the last few decades, however, collective bargaining has decentralized in many countries. Since the 1980s, collective bargaining in Western Europe has shifted away from national industry-wide bargaining toward the level of individual firms (Katz 1993; Supiot 2001; Traxler, Blaschke, and Kittel 2001). Today, company-level bargaining is often a part of the collective bargaining process. When bargaining predominately occurs at higher levels, firm-level negotiations frequently follow broader sectoral or national negotiations. Even more than in Western European nations, most (wage) bargaining in the new EU member states currently occurs at the local, company level (Welz and Kauppinen 2004; also see the data by Visser 2011).

\footnotetext{
*Giedo Jansen is a Postdoctoral Researcher at the Institute for Management Research, Nijmegen School of Management, Radboud University, Nijmegen, the Netherlands. This research was supported by the Dutch Science Foundation (NWO), grant 432-08-022. Correspondence can be directed to the author at g.jansen@fm.ru.nl.
} 
To date, however, company-level evidence regarding union organization and strike activity is limited. Because earlier studies at the company level (e.g., Blanchflower and Cubbin 1986; Gramm 1986; Drago and Wooden 1990; Machin, Stewart, and Van Reenen 1993; Dobson 1997) or negotiation level (e.g., Ingram, Metcalf, and Wadsworth 1993; Campolieti, Hebdon, and Hyatt 2005) have covered only one or a few companies or countries, the generalizability of these results is low. Moreover, because only a few studies have used cross-national data sets to examine the link between union organization and strike incidence, the findings concerning country-to-country differences in this relationship are inconclusive (e.g., the two-country comparisons of Coutrot [1998] as well as Whitfield, Marginson, and Brown [1994]). An additional shortcoming of these studies is that they were unable to measure and formally test the intervening effect of the national context; rather, they inferred that context matters based on the finding that the effects that local unions have on strikes sometimes differs by country. For example, Coutrot (1998) found that the ability of trade unions to initiate a strike is more dependent on membership levels in Britain than in France. He interpreted this finding as an effect of differences in legal constraints on the unions' abilities to organize collective action. Coutrot (1998: 190) argued that British unions "have been obliged to hold a ballot before launching a lawful strike, while their French counterparts have no such obligation." Although this interpretation suggests that the magnitude of the relationship between unions and strikes depends on national conditions, more stringent analyses are required to formally test whether the national labor context influences firm-level industrial relationships.

In this article I employ data from the European Company Survey, 2009 (ECS-2009) initiated by Eurofound. The data from this large-scale crossnational workplace survey in the European Union (EU) allow researchers to examine trade unions and strikes in more than 5,000 firms across all 27 EU member states. Using this data, I investigate the relationship between the organizational power of trade unions and industrial conflict in the EU while making three contributions to the literature. First, hypotheses are tested regarding union organization and strikes at the level of individual companies. A focus on local union organization has become increasingly relevant as a result of the move toward decentralized collective bargaining (Hancké 1993; Benson and Gospel 2008). Second, the strong comparative character of this study exceeds the scope of previous workplace studies. To my knowledge, no other study examines strikes within individual companies and compares more than two countries. Third, I conduct analyses that are not only cross-national but also multi- and cross-level in nature. Progress is made by supplementing the ECS-2009 data with country-level data from the database on Institutional Characteristics of Trade Unions, Wage Setting, State Intervention and Social Pacts (ICTWSS) (Visser 2011) and by using multilevel models to examine how national union characteristics influence the association between union organization and strikes in EU companies. Specifically, with this study I aim to answer two questions: 1) To what extent 
is strike incidence associated with union organization at the company level in EU countries? 2) To what extent do national trade union systems condition the company-level associations between strike incidence and union organization?

\section{The Need for a Company-Level Analysis in a Cross-National Perspective}

Differences in strike incidence are, from the perspective of resource mobilization (see Franzosi 1995), related to variations in union organization because unions facilitate the capacity and means for collective action. I assess the effects of three indicators of local trade union organization on strike incidence: union membership rate, multi-unionism, and union-dominated works councils. These indicators are related to strikes given that they either increase or decrease a union's organizational capacity in times of mobilization for collective action.

\section{Union Organization and Strikes at the Workplace}

Union membership rate is sometimes considered a key indicator for the "capacity to strike" (Shorter and Tilly 1974; Snyder 1975; Kaufman 1982). Scholars assume that the decision to strike is predominantly made by unions and that in principle only union members will strike (Snyder 1975). Therefore, the capacity to strike should increase as union membership among workers increases. The vast majority of previous studies examining the association between union membership and strikes have relied on observations at the country or state level. Workplace surveys can assess the extent to which this relationship is also observable at the level of individual firms. An examination of the international comparative literature, however, reveals that only a few workplace surveys are available, and these studies only modestly test the aforementioned relationship. For example, based on company-level data from British firms in the 1980s, Blanchflower and Cubbin (1986) found that higher rates of unionized manual workers are associated with a greater propensity for industrial action, including strikes. Coutrot (1998) compared British and French firms in the 1990s and concluded that, although the effect of union density is positive and significant in both countries, it was stronger in Britain than in France. "French unions are able to launch strikes even when they organize a small portion of the workforce, while British unions' ability to do so is more dependent on their levels of membership" (Coutrot 1998: 198). In the present study, I provide a more rigorous test of the relationship between membership rate and strikes by investigating this effect in companies across all EU countries.

Second, the number of trade unions represented at the workplace indicates a division within the labor movement (i.e., "multi-unionism"; Clegg 1976; Korpi and Shalev 1979; Dobson 1997; Akkerman 2008; Hartcourt and Lam 2011). When more than one trade union is available to represent 
workers, union competition may occur, which increases the potential for strikes. ${ }^{1}$ The empirical status of multi-unionism, however, is not clear. Early national-level studies demonstrated that union competition is not associated with higher levels of strikes in all countries. For example, Ross and Hartman (1960) noted that the Netherlands is a significant exception; although pervasive divisions exist within the labor movement, strikes do not occur frequently. Focusing on the sector level, Akkerman (2000) demonstrated that the relationship between multi-unionism and strikes differed across countries. The few available studies at the company level demonstrate a positive effect of multi-union representation on the number of strikes. An analysis of workplace surveys in Britain (Ingram et al. 1993; Machin et al. 1993; Dobson 1997) revealed that the presence of more than one union was associated with higher strike incidence than single unionism. Drago and Wooden (1990) reached a similar conclusion in an analysis of data from a 1988 survey of Australian workplaces. A drawback, however, of these studies is that they were restricted to Australia and the United Kingdom. To determine whether the conclusions from these studies hold in other settings, in this study I investigate the effect of multi-unionism in cross-national perspective.

Third, I will examine the effect of union-dominated works councils. The strength of a trade union may depend on specific organizational resources in individual firms. For example, Blanchflower and Cubbin (1986) showed that the presence of a shop steward was associated with a greater propensity for industrial action in the 1980s within British firms. Kelly (1996: 81) argued that unions can extend their influence at the workplace by engaging employers using non-bargaining channels, taking part in discussions on issues that are of common interest, such as training, health and safety, and productivity. In many EU countries, these issues are organized within local bodies for communication between management and the workforce (i.e., in works councils). Works council membership is rarely confined to trade unionists, although in so-called single-channel systems, unions possess a monopoly right of representation (see Gumbrell-McCormick and Hyman 2010). In practice, and especially in dual-channel systems in which unions and works councils formally have distinct bases of representation, the demarcation between union and nonunion representation is often unclear. Unions occasionally dominate works councils (Carley, Baradel, and Welz 2005). For example, the majority of councilors in large firms in Germany are union members (Kelly 1996; Gumbrell-McCormick and Hyman 2010). Visser (1995) argued that union-dominated councils help to sustain the organizing efforts of the union. Certain trade unions may be weak at the local workplace in terms of membership but may hold a strong position on works

\footnotetext{
${ }^{1}$ With respect to multi-union representation, the industrial relations systems in Europe differ substantially from those in North America (Akkerman 2008). Whereas multi-unionism disappeared after the 1935 Wagner Act in the United States, more than one union is often recognized for collective bargaining in Europe, both at the firm and sector levels.
} 
councils. Therefore, works councils may increase the capacity to strike when union-dominated.

In sum, this study reinvigorates the research on the relationship between the organizational strength of trade unions and industrial conflict using a large-scale analysis at the company level. To test whether, and to what extent, the relationship between union organization and strike incidence can be identified as a company-level phenomenon, I formulate the following hypotheses.

Hypotheses 1a-1c: Strikes are more likely in companies as

(1a) union membership is higher,

(1b) the number of unions is higher, and

(1c) works councils are union-dominated.

\section{The Interplay between Organizational Resources}

After formulating general hypotheses regarding the direct effects of union organization on strike incidence, I will specify the conditions under which these effects might be stronger or weaker. I focus on the interaction among the three types of union organization. First, I discuss the potential interplay between membership rates and multi-unionism. Following Hypothesis la, I expect that membership rates in companies are positively correlated with strike incidence given that a certain level of organization among employees is required for collective action (Franzosi 1989). Multi-unionism indicates trade union division and fragmentation (Ross and Hartman 1960; Clegg 1976; Korpi and Shalev 1979; Akkerman 2008). If Oswald's claim (1979) is correct and division within the labor movement leads to a lack of cooperation between rival unions, then multi-unionism will undermine the union's organizational capacity for mobilization. Different unions might not only represent different groups of employees but also articulate different interests and grievances. When two or more unions are represented at the workplace, I expect that the overall union membership rate in a firm will be less strongly correlated with strikes. Specifically,

Hypothesis 2a: The positive effect of union membership on strike incidence weakens as the number of unions increases.

A further potential interaction is between membership rate and the presence of a union-dominated works council. The hypothesis that strikes are more likely in companies with union-dominated works councils is based on the assumption that, under these circumstances, the union possesses additional organizational resources. Unions can, and may choose to, strengthen and extend their organizational capacity at the workplace by using works councils as alternative channels to communicate with employers and employees. Therefore, domination over works councils might make a union less dependent on general membership rates to mobilize employees and to organize a strike. Hence, 
Hypothesis 2b: The positive effect of union membership on strike incidence is weaker in companies where works councils are uniondominated.

Next, there may be interaction between the effects of multi-unionism and union-dominated works councils. If competition undermines interunion cooperation, then multi-unionism could fragment the unions' position in the works council. Under multi-unionism, employee representatives may be members in different unions with distinct membership compositions and interests. Therefore, I expect that when two or more unions are represented at the workplace, the overall numerical domination of trade unionists in a company's works council will be less strongly correlated with the occurrence of a strike. Thus,

Hypothesis 2c: The positive effect of union-dominated works councils on strike incidence weakens as the number of unions increases.

\section{Trade Union Systems: Company-Level Effects in Context}

As previously mentioned, only a few studies have investigated whether the national context influences labor relationships and collective action at the firm level using cross-national data sets (Whitfield et al. 1994; Coutrot 1998). The availability of the ECS-2009 data enables me to examine not only whether, and to what extent, differences occur between EU countries regarding the effect of union organization on strike incidence but also why these differences occur. Therefore, this study formally tests whether the relevance of local union organization differs across countries. The null hypotheses that no country differences exist should be rejected if trade union effects on strikes are country-dependent. Thus,

Hypothesis 3a-3c: The company-level effects on strike incidence regarding

(3a) union membership rates,

(3b) the number of unions, and

(3c) union-dominated work councils

will be different across EU countries.

To study why there might be cross-national differences in the association between union organization and strike incidence within companies, I will explore the interplay between company-level and country-level organizational resources. The primary argument to do so is that trade unions might rely on a combination of central and decentralized organizations, and national unions might function as a pool of support and resources for local unions (Hancké 1993), constrain local union autonomy (Benson and Gospel 2008), or both. In this respect, resources and constraints for mobilization may relate to location of the decisions concerning union activities, to 
where the funds are held and spent, and to sources of recognition and legitimacy (Benson and Gospel 2008). The capacity of local unions to engage in industrial conflict should therefore be studied with regard to national union structures. I focus on three features of the trade union system that might strengthen or weaken the union-organization effects at the firm level (i.e., a country's degree of union density, its number of trade union confederations, and its level of decentralization in the trade union movement).

Union density is often a macro-level indicator of the power of a labor movement and its organizational capacity. The use of this indicator relates to the micro-level expectation that higher membership rates in companies are positively correlated with the occurrence of strikes. Furthermore, the resources for organizing and initiating a strike in companies might also be greater when national levels of union density are higher. For example, the number of fee-paying members will partially determine the amount of financial resources that a union has at its disposal. National unions might finance local branches or allocate money to strike funds. To enable a strike, workplace branches might benefit from the resources of national unions or confederations. Consequently, local branches will be less dependent on company-level resources when national membership rates are high.

Hypothesis 4: The company-level effects of union organization on strike incidence are weaker in countries where union density is higher.

Similarly, I expect a moderating effect of the fragmentation of a country's labor movement. As I argued earlier, multi-unionism will undermine the organizational resources that are associated with high membership rates. In addition to multi-unionism at individual companies, however, the fragmentation of the national labor movement may have a similar effect. In a country in which the labor movement is divided into a wide array of trade unions and union confederations, the various unions may articulate different interests and grievances, diminishing the capacity to mobilize members at the workplace. This observation leads to my second cross-level interaction hypothesis.

Hypothesis 5: The company-level effects of union organization on strike incidence are weaker in countries where the number of confederations is higher.

Finally, I investigate the degree of decentralization in the national labor movement. I expect that the capacity for the collective action of local unions depends on their own autonomy and, in turn, the control of national confederations. Greater independence of local branches and representatives might advance the capacity of workplace unions to initiate a strike. The autonomy of a local union might be greater when national interventions in company-level negotiations are few, no vetoes are passed on enterprise strikes, 
and the local union has independent control over finances or over the appointment of workplace representatives (Benson and Gospel 2008; Visser 2011). Under these circumstances, workplace branches will have greater autonomy to launch a strike without being constrained by the regulations of the national trade union. Therefore, I expect that the local union branches of countries with decentralized unions will depend less on organizational factors for the initiation of a strike.

Hypothesis 6: The company-level effects of union organization on strike incidence are weaker in countries where the union movement is more decentralized.

\section{Data, Measures, and Methods}

I use data from the European Company Survey, 2009 (Eurofound and TNS Infratest 2010). The ECS-2009 is a large-scale representative survey of firms in both the private and public sectors across all EU-27 countries and three acceding and candidate countries (i.e., Croatia, Macedonia, and Turkey). Interviews with managers and employee representatives were conducted in more than 27,000 companies with 10 or more employees. Approximately all sectors of activity (NACE rev.1.1) were included in the sample with the exception of the agricultural sector, private households, and extraterritorial organizations. Management interviews, with the most senior official responsible for personnel in each firm, were conducted in all companies $(N=27,160)$. Interviews with an employee representative, preferably the chairperson of the most important employee representative body in the firm, were conducted in approximately $25 \%$ of the companies $(N=6,569) .{ }^{2}$ Because information on strikes, union organization, and works councils must be obtained from the interview with the employee representative, I am able to include only firms with both types of interviews. The analyses include only companies from EU-27 countries without missing information on relevant variables. Ultimately, the sample contains 5,873 companies.

The ECS-2009 data are used to conduct a series of multilevel analyses that combine information on EU companies with the characteristics of the countries from which they were established. Because the dependent variable, strike incidence, is dichotomous, I estimate a logistic model. In doing so, I employ a two-level hierarchical design in which companies (Level 1) are nested within countries (Level 2). At the lowest level $(N=5,873)$, I include variables related to union organization at the workplace (i.e., union membership rate, multi-unionism, and union-dominated works councils). To account for differences between individual companies and their likelihood of experiencing industrial action, I control for company size, the economic sector of activity, status (i.e., independent, subsidiary site, or headquarters),

\footnotetext{
${ }^{2}$ For a more comprehensive discussion of the ECS-2009, consult the Technical Report (Riedmann 2009).
} 
public ownership, and the level upon which the collective agreement in each company, if any, was negotiated. At the highest level $(N=27),{ }^{3}$ countryspecific variables related to the trade union system are included using information for 2008 from the ICTWSS database (Visser 2011). I discuss the measurement of my key variables in greater detail below. Descriptive statistics are presented in Appendix A.

\section{Dependent Variable}

I measure strike incidence using reports on industrial action from the employee representative. Respondents were asked whether there have been one or more instances of industrial action in their establishment over the past 12 months, and if so, what form of action this took: 1) stoppage of work or strike; 2) strike of one day or more; 3) refusal to work overtime; and 4) other actions. Unfortunately, the first two response categories are not mutually exclusive and do not allow me to differentiate between work stoppages and strikes. Therefore, I construct a binary variable $(1 / 0)$ to distinguish companies in which at least one strike or work stoppage occurred over the past 12 months (collapsing Category 1 and 2) from companies with no or other forms of industrial action (collapsing Categories 3 and 4 with all companies without reported industrial action) ${ }^{4}$

\section{Independent Variables}

\section{Union Membership Rate}

Employee representatives estimated the proportion of employees in their establishment who belonged to a trade union. When the employee representative was not aware of this information, he or she was asked to make an estimation, using fixed categories of "none," "less than 20\%," "20\% to less than $40 \%$," " $40 \%$ to less than $60 \%$," "60\% to less than $80 \%$," "80\% to less than $100 \%$," or "All." When an estimate was reported as a category, I recode this information into a proportion by taking the category midpoint (e.g., "20\% to less than $40 \%$ " is recoded as $30 \%$ ). I recode this variable so that it ranges from 0.0 (no union members) to 10.0 (100\% union members).

\section{Number of Unions}

I use the number of trade unions represented at the workplace as a proxy for multi-unionism. The maximum number of unions is truncated at 11,

\footnotetext{
${ }^{3}$ There are varying rules of thumb regarding the minimum number of observations in multilevel analysis. In general, these rules suggest that greater numbers at both levels increase the accuracy of the estimates and standard errors. With respect to the country level, advice ranges from no minimum (Gelman and Hill 2007) to at least 50 (for a discussion see Hox 2010). The current research investigates countries in the EU; therefore, 27 is the maximum number of country-level observations.

${ }^{4}$ Alternative coding of the dependent variable, for example, contrasting any form of action with no action at all, produces similar results to those presented in this article.
} 
and only $0.4 \%$ of the firms reported more than 11 unions. Note that this measure disregards the potential dissimilarities in the bases for distinctions among unions (e.g., occupational, political, or religious divisions). Multiunionism may only be related to interunion competition when two or more unions represent the same type of workers. Unfortunately, the ECS data do not permit the study of this feature of multi-unionism.

\section{Union-Dominated Works Councils}

I measure union membership among employee representatives in a manner similar to the procedure that measures union membership rate among the workforce. I use this information to construct a dummy variable that indicates whether the majority $(>50 \%)$ of the works councilors are union members (1) or not (0).

Before including the union organization variables into the analyses, two transformations are conducted. First, I transform union membership rate and the number of unions into their natural logarithm. By taking the logarithm of both variables, I account for the fact that the effects of union membership rate and the number of unions on strike incidence might not be linear. Preliminary analyses demonstrate that with the $\log$ transformations, the models presented in this article yield a better model fit, ${ }^{5}$ suggesting that there may be diminishing returns in the effects of union membership rate and the number of unions on strikes. Second, all three variables are centered at the country mean. Using group-mean centering is often recommended in multilevel modeling when interaction effects are of substantive interest, especially when cross-level interactions are involved. Without centering, or with grand-mean centering, cross-level interactions are sometimes confounded with between-group interactions (cf. Hofmann and Gavin 1998; Enders and Tofighi 2007; Hox 2010). Because this recommendation stands "regardless of whether the predictor is continuous or binary" (Enders and Tofighi 2007: 135), I also centered the dummy-variable for union-dominated works councils at its country-mean value.

\section{Country-Level Variables}

\section{Union Density Rate}

This variable from the ICTWSS database measures the net union membership as a proportion of the wage and salary earners in employment (i.e., the total number of union members [minus union members outside the active labor force]*100, divided by the number of employed-wage and salary

\footnotetext{
${ }^{5}$ In multilevel modeling, Akaike's Information Criterion (AIC) is used as a general fit index (Hox 2010). The model with the lowest AIC value is usually the preferred model. The AIC statistic of the model with the log transforms was 3391, whereas this value was 3404 for the model with a linear effect of union membership rate and 3398 for the model with a linear effect of multi-unionism. The effect of multiunionism was not significant without the logarithmic transformation.
} 
workers in the OECD Labour Force Statistics). This variable ranges from 7.27 in Estonia to 68.27 in Sweden.

\section{Number of Confederations}

The number of union confederations in the ICTWSS database ranges from 1 to 7 . Only central organizations are included (i.e., confederations with affiliate unions and memberships that exceed $5 \%$ of the total union membership in that country). Smaller confederations are ignored and considered part of the independent, autonomous, or unaffiliated union membership.

\section{Union Decentralization}

The ICTWSS database includes a summary measure of the power that unions have over their local or workplace branches and representatives. This measure is the sum of five items that are measured on a 3-point scale $(0-2)$ : union power in local wage bargaining, appointment of workplace representatives, finances of local branches, strike funds, and strike vetoes. In Visser's original calculation, the maximum value referred to the situation in which the union has "full" authority over local branches. I reverse this variable to measure the degree of "union decentralization." In the countries that I study, the metric ranges from 0 for "centralized union system" to 7 for "decentralized union system." In the analyses, all three country-level variables are included as mean-centered covariates.

\section{Results}

\section{Company-Level Effects}

In Table 1, I present the results of the multilevel logistic regression analysis of strike incidence. ${ }^{6}$ Model 1 includes five sets of control variables at the company level. First, I control for economic activity based on 1-digit NACE categories with manufacturing and energy (NACE Categories C, D, and E) as references. Compared with firms in these categories, I find that strikes are less likely in most other industries. Only in education (NACE M) do I find that the odds of experiencing a strike are approximately twice as high $\left(\mathrm{e}^{0.699}\right)$. Strikes are least common in the finance and intermediation industry (NACE J).

Second, I control for public sector firms. The positive effect (0.663) indicates that strikes are almost twice as likely in public sector firms compared with privately owned firms. To account for cross-national differences in strike rights for the public sector, I allow a random slope for the effect of

\footnotetext{
${ }^{6}$ All models are estimated using the lme4 package in R (Bates, Maechler, and Bolker 2011). To construct Figure 1, I adapted a piece of R code from Kastellec and Leoni (2007). Figure 2 was constructed using a function by Bayen (2011).
} 
Table 1. Results of the Multilevel Logistic Analysis of Strike Incidence in EU Companies

\begin{tabular}{|c|c|c|c|c|}
\hline \multirow[b]{2}{*}{ Variable } & \multicolumn{2}{|c|}{ Model 1} & \multicolumn{2}{|c|}{ Model 2} \\
\hline & $b$ & $(S E)$ & $b$ & $(S E)$ \\
\hline Fixed effects & $-3.931 * * *$ & $(0.37)$ & $-3.843^{* * *}$ & $(0.37)$ \\
\hline \multicolumn{5}{|l|}{ Constant } \\
\hline \multicolumn{5}{|l|}{ Company-level variables } \\
\hline \multicolumn{5}{|c|}{ Economic activity ${ }^{\mathrm{a}}$ (NACE CDE $=$ reference) } \\
\hline NACE F & $-0.598 * *$ & $(0.30)$ & $-0.624 * *$ & $(0.30)$ \\
\hline NACE G & $-0.566 * *$ & $(0.23)$ & $-0.571^{* *}$ & $(0.23)$ \\
\hline NACE H & $-0.782 *$ & $(0.46)$ & -0.748 & $(0.46)$ \\
\hline NACE I & -0.184 & $(0.24)$ & -0.154 & $(0.24)$ \\
\hline NACE J & $-0.924 * *$ & $(0.42)$ & $-0.920 * *$ & $(0.42)$ \\
\hline NAce K & $-0.730 * * *$ & $(0.26)$ & $-0.760 * * *$ & $(0.26)$ \\
\hline NACE L & -0.113 & $(0.20)$ & -0.161 & $(0.20)$ \\
\hline NACE M & $0.699 * * *$ & $(0.20)$ & $0.644 * * *$ & $(0.20)$ \\
\hline NACE N & 0.094 & $(0.18)$ & 0.084 & $(0.18)$ \\
\hline NACE O & $-0.565^{* *}$ & $(0.28)$ & $-0.543 *$ & $(0.28)$ \\
\hline Public sector & $0.663 * * *$ & $(0.23)$ & $0.705^{* * * *}$ & $(0.23)$ \\
\hline \multicolumn{5}{|c|}{ Company size (10-19 employees = reference) } \\
\hline $20-49$ & 0.368 & $(0.22)$ & 0.363 & $(0.22)$ \\
\hline 50-99 & 0.332 & $(0.23)$ & 0.316 & $(0.23)$ \\
\hline 100-199 & $0.688 * * *$ & $(0.23)$ & $0.667 * * *$ & $(0.23)$ \\
\hline 200-399 & $0.857 * * *$ & $(0.23)$ & $0.825 * * *$ & $(0.23)$ \\
\hline $400-500$ & $1.070 * * *$ & $(0.27)$ & $1.047 * * *$ & $(0.27)$ \\
\hline $500+$ & $1.330 * * *$ & $(0.23)$ & $1.327 * * *$ & $(0.23)$ \\
\hline \multicolumn{5}{|c|}{ Company status (independent $=$ reference) } \\
\hline Headquarters & $0.261 * *$ & $(0.13)$ & $0.256 * *$ & $(0.13)$ \\
\hline Subsidiary site & $0.486 * * *$ & $(0.13)$ & $0.491 * * *$ & $(0.13)$ \\
\hline Unknown & 0.212 & $(0.27)$ & 0.217 & $(0.27)$ \\
\hline \multicolumn{5}{|c|}{ Collective agreement (company level = reference) } \\
\hline None & -0.251 & $(0.19)$ & -0.233 & $(0.19)$ \\
\hline Higher level & $0.330 * * *$ & $(0.12)$ & $0.327 * * *$ & $(0.12)$ \\
\hline Mixed & -0.280 & $(0.20)$ & -0.276 & $(0.20)$ \\
\hline \multicolumn{5}{|l|}{ Company-level union organization } \\
\hline (In) Union membership rate ${ }^{b}$ & $0.574 * * *$ & $(0.10)$ & $0.596 * * *$ & $(0.10)$ \\
\hline (In) Multi-unionism ${ }^{\mathrm{b}}$ & $0.361 * * *$ & $(0.12)$ & $0.386 * * *$ & $(0.13)$ \\
\hline Union-dominated works council & $0.296 * * *$ & $(0.11)$ & $0.382 * * *$ & $(0.13)$ \\
\hline \multicolumn{5}{|l|}{ Interactions } \\
\hline Union membership x Multi-unionism & & & $-0.466^{* *}$ & $(0.21)$ \\
\hline Union membership x Works council & & & -0.249 & $(0.19)$ \\
\hline Works council x Multi-unionism & & & -0.220 & $(0.27)$ \\
\hline \multicolumn{5}{|l|}{ Random Effects } \\
\hline Variance at Country Level & 1.96 & $(1.40)$ & 1.92 & $(1.38)$ \\
\hline Random Slope Public Sector & 0.56 & $(0.75)$ & 0.58 & $(0.76)$ \\
\hline AIC & 3391 & & 3385 & \\
\hline
\end{tabular}

Notes: $\mathrm{N}_{\text {level-1 }}=5,873 ; \mathrm{N}_{\text {level-2 }}=27$.

${ }^{a} \mathrm{NACE}$ : $\mathrm{CDE}=$ Manufacturing and energy; $\mathrm{F}=$ Construction; $\mathrm{G}=$ Wholesale and retail trade; repair of motor vehicles, motorcycles and personal and household goods; $\mathrm{H}=$ Hotels and restaurants; $\mathrm{I}$ = Transport, storage and communication; $\mathrm{J}=$ Financial intermediation; $\mathrm{K}=$ Real estate, renting and business activities; $\mathrm{L}=$ Public administration and defense; compulsory social security; $\mathrm{M}=$ Education; $\mathrm{N}=$ Health and social work; $\mathrm{O}=$ Other community, social and personal service activities.

${ }^{\mathrm{b}}(\ln )=$ natural logarithmic transformation

* Statistically significant at the .10 level; ** at the .05 level; *** at the .01 level (two-tailed test). 
public sector firms on strike incidence; thus, I let public sector firms have a different effect on strikes across the range of countries in the study. A likelihood ratio test revealed that the random slope model fit the data better than a model with only a fixed coefficient for the public sector $\left(\operatorname{LR} \chi^{2}=19.3\right.$, $\mathrm{df}=2$ ). Nevertheless, this random-effects model suggests that a positive slope for public sector establishments is found in most countries. ${ }^{7}$

Third, I account for company size, which is measured using seven categories with the smallest category (10-19 employees) applied as the reference. I find that strikes are more likely as the firm size increases. Relative to the smallest category of firms, the odds of larger firms experiencing a strike are nearly twice as high $\left(\mathrm{e}^{0.688}\right)$ when there are 100 to 199 employees, and this finding amounts to 2.3 times, 2.9 times, and 3.8 times for workplaces with 200 to 399,400 to 500 , and $500+$ employees, respectively.

Fourth, I control for whether the companies are single and independent organizations (the reference) or part of a larger organization (differentiating between headquarters and subsidiary sites). I also include a dummy indicator for companies in which the manager did not provide clear status information. I find that the odds of experiencing a strike are approximately 1.6 times higher in subsidiary sites compared with independent firms $\left(\mathrm{e}^{0.486}\right)$.

Fifth, I include a set of control variables to indicate whether, and at what level, a collective wage agreement covers employees. The reference category consists of firms in which the collective agreement is negotiated at the company level. I find a positive effect for the dummy variable, indicating that the collective agreement is negotiated at a higher level $(0.330)$. This result suggests that the odds of having a strike are 1.4 times higher when a collective agreement is in place at a higher level than the firm.

\section{Union Organization Effects}

Model 1 supports Hypotheses 1a-1c regarding the relationship between union organization and strikes. All three union organization effects are positive and significant. The positive effects of union membership rate $(0.574)$ and multi-unionism (0.361) confirm Hypotheses 1a and 1b. Strikes are more likely to occur in companies where 1a) union membership is high and 1b) the number of unions is high. Moreover, I find a positive and significant effect of union-dominated works councils $(0.296)$. This effect implies that companies in which trade union members make up more than $50 \%$ of the local works council are 1.3 times $\left(\mathrm{e}^{0.296}\right)$ more likely to experience a strike than companies without a union majority in the works council. Hence,

\footnotetext{
${ }^{7}$ In most countries, the country-specific slope does not deviate from the mean slope $(0.663)$. The public sector effect is stronger than average for the Czech Republic, Denmark, Hungary, Poland, Portugal, and the United Kingdom, whereas this effect is weaker than average in the Netherlands. The effect in Finland is negative $(-0.828)$, which indicates that Finnish public sector establishments are less likely to strike than private sector companies.
} 
Hypothesis $1 \mathrm{c}$ is also confirmed: strikes are more likely in companies with union-dominated works councils.

\section{Company-Level Interaction Effects}

To test Hypotheses 2a, 2b, and 2c, I model interactions between the three union organization variables. Hypothesis 2a states that strikes are more likely in companies as union membership increases but that this effect is weaker when many unions are at the workplace. For this hypothesis to be supported, I must find a negative effect in the interaction between union membership rate and multi-unionism. This finding is confirmed in Model 2 (Table 1). The main effect of membership rate $(0.596)$ indicates that membership rate has a positive effect on strike incidence when the log number of unions is at its country-mean value. However, the negative interaction effect $(-0.466)$ indicates that membership rate has a weaker and eventually negative effect on strikes when the log number of unions at the workplace is greater than the country average. This finding suggests that higher membership is associated with more strikes only when interunion competition is relatively low. In multi-union companies, the capacity to mobilize members may diminish because the various unions have a different membership base and articulate different interests.

Model 2 shows no support, however, with respect to the other interaction hypotheses. In spite of Hypothesis $2 \mathrm{~b}$, the interaction between union membership rate and union-dominated works councils is not found to be significant. Hence, the effect of membership rate on strike incidence is not weaker in companies with a union-dominated works council. This contradicts the expectation that domination over works councils would make a union less dependent on general membership rates to mobilize employees and organize a strike. Also, no statistically significant interaction is found between union-dominated works councils and the number of unions. Therefore, Hypothesis 2c, stating that the positive relationship between works council domination and strikes would be weaker when the number of unions is higher, is not supported. Based on these findings, nothing upholds the assumption that multi-unionism would undermine the organizational capacity of union-dominated works councils.

\section{Cross-National Differences}

\section{Country-Specific Effects of Union Organization}

To examine whether the influence of the company-level effects of union organization on strike incidence differs across countries, I extend Model 1 to include three random slopes, one for each union organization variable. Thus, I allow union membership rate, multi-unionism, and union-dominated works councils to have a different effect with regard to strikes in each country (henceforth, the union organization random effects model). These countryspecific effects (calculated as the mean slope + deviation from mean slope \pm 
standard error; cf. Gelman and Hill 2007) are displayed in Figure 1. The dashed vertical line in each figure is the mean slope of this effect across all the countries. The dot plots and error bars indicate the country-specific slope coefficients and their standard error intervals, respectively. By visualizing the random effects in this manner, I can determine the extent to which a country-specific effect differs from the mean slope (caution is needed in interpreting country-specific effects as relative to each other [Gelman and Hill 2007: 271]). Figure 1 indicates that Hypothesis 3, which states that differences occur among countries with regard to the company-level effects of union organization on strike incidence, is supported.

Figure 1A shows that the mean slope of union membership rate is 0.63 , and this effect is significant at the .01 level. Consistent with Table 1 , this finding indicates that an increase in membership rate is, on average, associated with higher likelihood of experiencing a strike. The error bars for the majority of countries overlap with the mean slope, which suggests that the extent to which membership rate is associated with strike incidence is approximately similar and positive for most countries. This effect is weaker for four countries compared with the average. In particular, the results suggest that launching a strike is less dependent on the company-level unionization rate in Greece and Italy. In these countries, relatively few union members are needed to start a strike. The effect of membership rate is stronger than average for Germany and, on the borderline, for Austria. Here, initiating a strike requires a relatively strong membership base.

Figure $1 \mathrm{~B}$ shows that a large amount of variation occurs across countries with regard to the associations between multi-unionism and strike incidence. Consistent with Table 1, the mean slope of multi-unionism is positive (0.42), which indicates that, on average, strikes are more likely in companies in which the number of unions is higher. Figure $1 \mathrm{~B}$ shows that this positive effect is particularly strong in the Netherlands, Luxembourg, and Belgium. In these countries, each additional union is more likely to be associated with the occurrence of a strike than in most other countries. For the majority of the countries, however, I find no indication that the effect of multi-unionism is substantially different from the average effect. Only in six countries is the association between the number of unions at the workplace and the likelihood of a strike clearly weaker, and potentially even negative. A negative effect of multi-unionism (as in Denmark, Poland, and maybe the United Kingdom) would suggest that strikes are less likely in companies in which the number of unions is high.

I also find differences among countries with regard to the effect of uniondominated works councils. The mean slope in Figure 1C is not significant, which indicates that, on average, whether union members dominate the employee representative body in a company does not matter. For many countries, the error bars in Figure 1C overlap with the mean slope, and this result suggests that union-dominated works councils do not affect strike incidence in those countries. In the top six countries, however, I find a positive effect of union-dominated works councils, and this effect is the strongest 
Figure 1. Random Effects of Union-Organization Variables on Strike Incidence in EU Companies ${ }^{\mathrm{a}}$

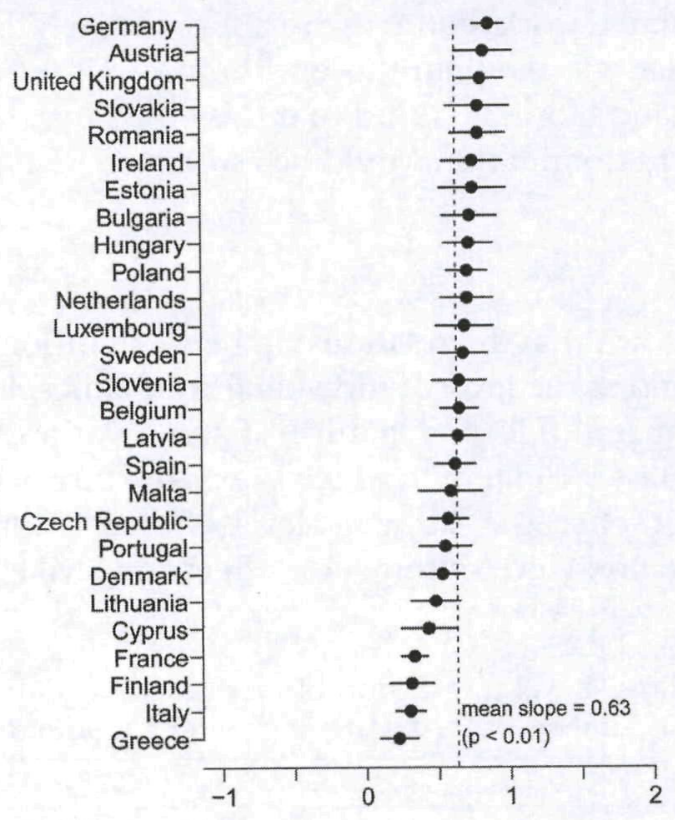

A. Country-specific effects of union membership rate on strike incidence

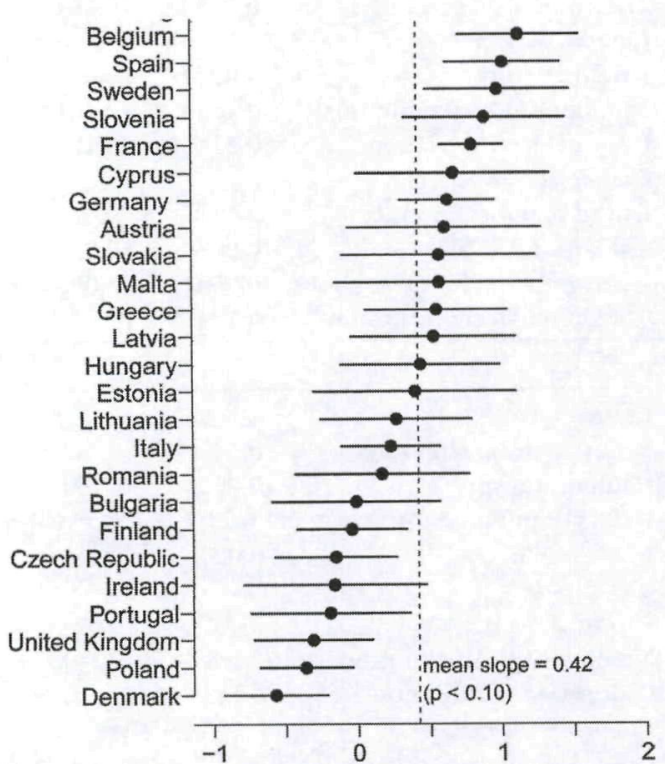

B. Country-specific effects of multi-unionism on strike incidence

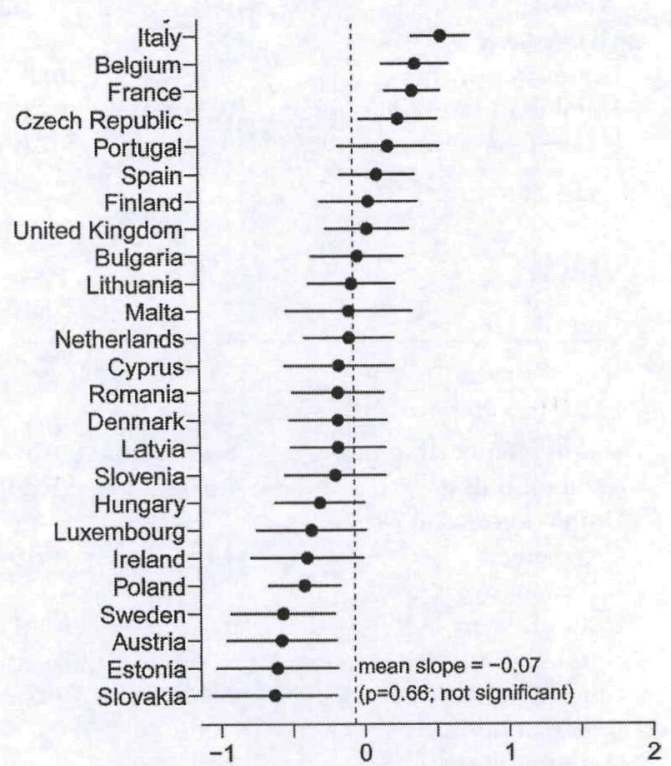

C. Country-specific effects of union-dominated works councils on strike incidence

${ }^{a}$ The dashed vertical line in each figure represents the mean slope across all countries. The dot plots and error bars indicate the country-specific slope coefficients and their standard error intervals, respectively. 
for companies in Greece and Germany (Figure 1G). The country-specific slope in these countries is approximately 1 , which indicates that companies with union-dominated works councils are approximately 2.7 times $\left(\mathrm{e}^{1}\right)$ more likely to experience a strike than those without. In other countries, such as Sweden, Austria, and Slovakia, I find that this effect may be reversed, which suggests that union domination would be associated with fewer strikes.

\section{Cross-Level Interaction Effects}

Thus far, I have shown that the relationship between union organization and strikes can be found at the level of individual companies. I have also demonstrated that the magnitude and nature of this relationship differs across countries. Next, I test the extent to which the characteristics of national trade union systems influence the company-level effects of union organization. Table 2 shows the cross-level interaction effects on strike incidence. These

Table 2. Cross-Level Interaction Effects Based on a Multilevel Logistic Analysis of Strike Incidence in EU companies ${ }^{(a)}$

\begin{tabular}{|c|c|c|c|c|c|}
\hline \multicolumn{4}{|c|}{ Model 3} & \multicolumn{2}{|c|}{ Model 4} \\
\hline Company-level & & & Company-level & & \\
\hline Union membership rate & $0.564 * * *$ & $(0.12)$ & Union membership rate & $0.759 * * *$ & $(0.13)$ \\
\hline Multi-unionism & $0.382 * *$ & $(0.22)$ & Multi-unionism & $0.382 *$ & $(0.22)$ \\
\hline $\begin{array}{l}\text { Union-dominated works } \\
\text { council }\end{array}$ & -0.162 & $(0.19)$ & $\begin{array}{l}\text { Union-dominated works } \\
\text { council }\end{array}$ & -0.175 & $(0.1$ \\
\hline Country-level & & & Country-level & & \\
\hline Union Density & $0.029 * *$ & $(0.01)$ & Union Density & $0.030^{* *}$ & $(0.01)$ \\
\hline Number of Confederations & $0.284 * * *$ & $(0.10)$ & Number of Confederations & $0.284^{* * *}$ & $(0.10)$ \\
\hline \multirow[t]{6}{*}{ Union Decentralization } & $0.440 * * *$ & $(0.12)$ & Union Decentralization & $0.418^{* * * *}$ & $(0.12)$ \\
\hline & & & Cross-level Interactions & & \\
\hline & & & $\begin{array}{l}\text { Union membership rate } \\
\times \text { Union Density }\end{array}$ & & \\
\hline & & & $\times$ Number of Confederations & -0.056 & $(0.0$ \\
\hline & & & $\times$ Union Decentralization & $-0.124 * *$ & $(0.0$ \\
\hline & \multicolumn{2}{|c|}{ Model 5} & & \multicolumn{2}{|c|}{ Model 6} \\
\hline Company-level & & & Company-level & & \\
\hline Union membership rate & $0.552 * * *$ & $(0.12)$ & Union membership rate & $0.549 * * *$ & $(0.11)$ \\
\hline Multi-unionism & $0.519 * *$ & $(0.20)$ & Multi-unionism & $0.462 * *$ & $(0.22)$ \\
\hline Union-dominated works & & & Union-dominated works & & \\
\hline council & -0.136 & $(0.19)$ & council & -0.025 & $(0.18$ \\
\hline Country-level & & & Country-level & & \\
\hline Union Density & $0.028 * *$ & $(0.01)$ & Union Density & 0.003 & $(0.02)$ \\
\hline Number of Confederations & $0.300 * * *$ & $(0.10)$ & Number of Confederations & $0.281 * *$ & $(0.14)$ \\
\hline Union Decentralization & $0.428 * * *$ & $(0.12)$ & Union Decentralization & 0.141 & $(0.15)$ \\
\hline Cross-level Interactions & & & Cross-level Interactions & & \\
\hline Multi-unionism & & & Union-dominated works council & & \\
\hline$\times$ Union Density & $-0.030 * * *$ & $(0.01)$ & × Union Density & $-0.023^{* *}$ & $(0.01)$ \\
\hline$\times$ Number of Confederations & 0.006 & $(0.08)$ & $\times$ Number of Confederations & -0.019 & $(0.08)$ \\
\hline$\times$ Union Decentralization & $-0.296 * * *$ & $(0.11)$ & $\times$ Union Decentralization & $-0.262 * * *$ & $(0.09)$ \\
\hline
\end{tabular}

Notes: Controlled for economic activity, company size, company status, public sector and the level of collective agreement (see Table 1).

* Statistically significant at the .10 level; ** at the .05 level; *** at the .01 level (two-tailed test). 
models are built by extending the union organization random effects model; however, because of space limitations, I present only the interaction coefficients between union organization at the individual firms and the country-level union characteristics. First, in Model 3, I simultaneously include the context variables. The direct effects of union density (0.029), the number of confederations (0.284), and union decentralization (0.440) suggest that companies are more likely to experience strikes in countries where union density and the number of confederations are high, and where trade union movement is decentralized. In the subsequent models (4, 5, and 6), I compute the cross-level interaction effects. I plot the interactions that are significant at the 0.10 level or better to ease interpretation (see Figure 2).

The cross-level interaction hypotheses state that the company-level effects of union organization on strike incidence are weaker in countries with higher levels of union density, with more confederations, and with a decentralized union system. To support these hypotheses, negative interaction effects should appear between a company's union membership rate (Model 4), multi-unionism (Model 5), union-dominated works councils (Model 6), and the country-level variables.

The results show that the firm-level association between union organization and strikes is influenced by national context, especially a country's degree of union decentralization seems to matter. In Model 4, a negative interaction coefficient is found between a country's degree of union decentralization and the company-level effect of union membership rate. Figure 2A clearly shows that the positive effect of membership rate on strike incidence is weaker in countries with a decentralized labor movement and stronger in countries with a more centralized labor movement. Model 5 shows significant negative interaction between a country's degree of union decentralization and multi-unionism. As indicated in Figure 2B, this interaction implies that the impact of multi-unionism on strikes is negative in decentralized union systems but positive in centralized systems. Figure 2C, based on Model 6, shows a similar pattern for the interaction between a country's degree of union decentralization and the union-member domination of the local employee representative body. The effect of uniondominated councils on strikes is positive in countries in which union decentralization is low, but this effect is negative when union decentralization is high. ${ }^{8}$

Table 2 also demonstrates some support for the moderating effect of the national levels of union density. As expected, the interactions between the union organization variables at the company level and the union density rate at the country level are negative and significant, except for company-level

\footnotetext{
${ }^{8}$ To eliminate the possibility that the country-specific effects of union-dominated works councils are artifacts of the differences in the status and structure of disparate EU nations (Gumbrell-McCormick and Hyman 2010), I calculated the interaction between the union domination over the local works council and the type of system (dual vs. single channel systems). This interaction was not significant, nor was the effect of the works council stronger in countries with greater legal mandates.
} 


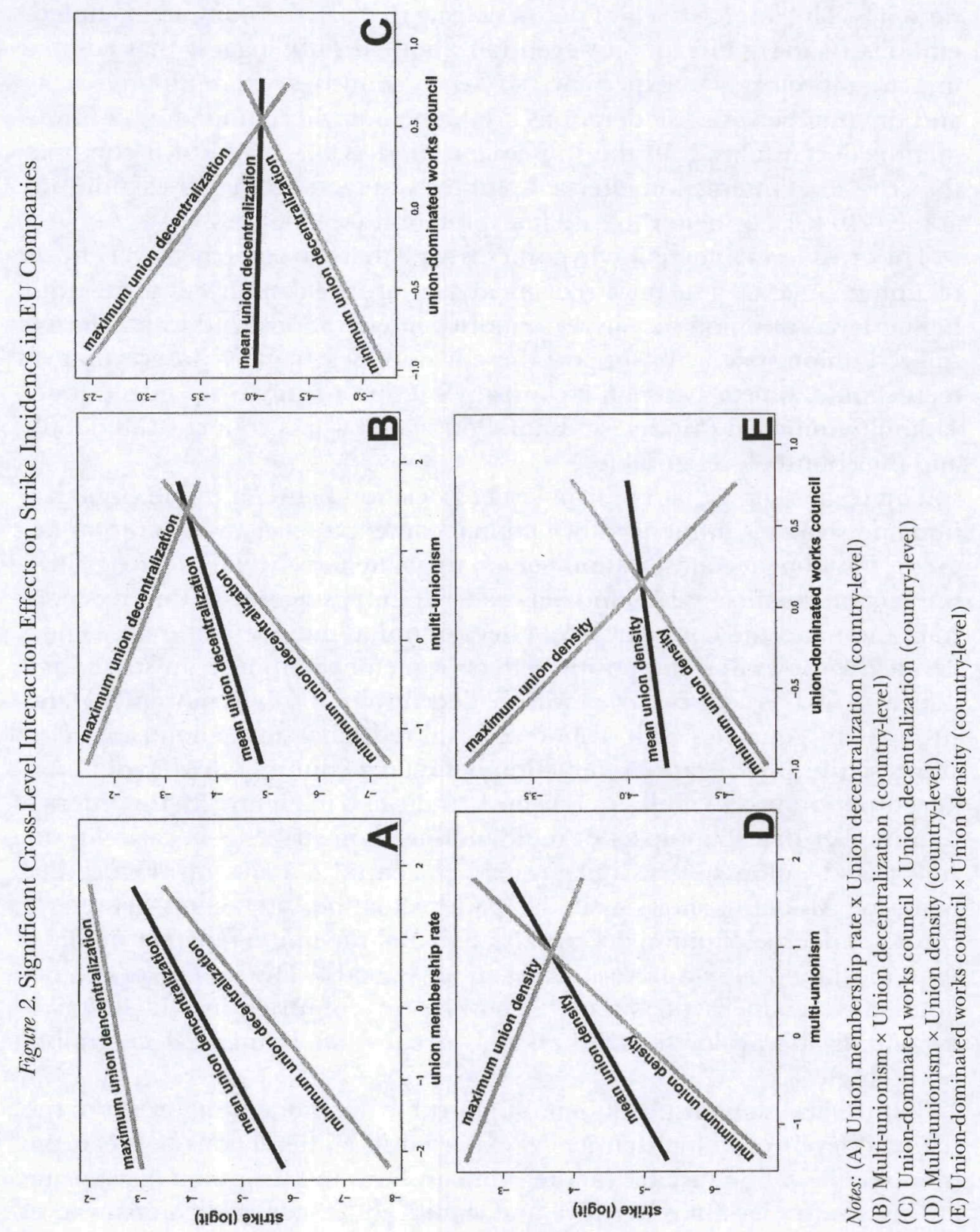


union membership (Model 4). Model 5 clearly shows that the positive effect of multi-unionism (0.519) on strike incidence is weaker when the union density rate at the country level increases $(-0.030)$. This finding might support the assumption that multi-unionism is positively associated with strike incidence because competing unions use strikes to attract new members (Dobson 1997). There might be less need for unions to attract new members when national membership rates are high. At maximum union density, the effect of multi-unionism is even negative, see Figure 2D. Again, a similar pattern is found for the interaction between country-level union density and union domination over the local works council. Figure 2E, based on Model 6, shows that the effect of union-dominated councils on strikes is positive in countries with low union density, but this effect is negative when union density is high.

All in all, Table 2 provides strong support for Hypothesis 6 on the impact of union decentralization and moderate support for Hypothesis 4 on the role of national union density. Hypothesis 5 , however, cannot be confirmed. The number of union confederations in a country does not influence any of the company-level union organization effects.

\section{Conclusion}

In this article, I investigated the occurrence of strikes in EU companies. First, I determined the extent to which union organization was associated with strike incidence at the level of individual firms. The analyses based on large-scale, cross-national, and firm-level data demonstrate clear evidence that local union organization affects the likelihood that a company will experience a strike. I have shown that the proportion of union members in the workforce, the number of represented unions, and the majority of union members who serve as employee representatives generally increase the incidence of strikes in a company. My findings not only confirm that the relationship between union organization and strikes exists at the company level but also prove that the interplay between different types of organization may lead to different outcomes in disparate companies. On the one hand, I have shown that the organizational resources associated with high membership density can be undermined by interunion competition. On the other hand, however, no evidence supports that multi-unionism undermines the organizational capacity of union-dominated works councils. Nor do I find that a strong position on the works council substitutes the organizational resources of high levels of union membership. Yet, this research shows that the effects of union organization on strike incidence depend on the constellation of local union resources and constraints.

Next, I showed that the company-level effects of union organization on strikes vary across countries. Previous studies have already suggested that the extent to which organizational resources are associated with the ability of unions to initiate a strike differs across countries. Previous studies, however, did not conduct large-scale comparisons. By analyzing more than 5,000 
firms across all EU member states, I have demonstrated, for example, that the effect of the membership rate on strike incidence is smaller in France, Greece, and Italy compared with many other countries. This finding provides a broader international perspective for Coutrot's (1998) observation that the ability of unions to initiate a strike in France is less dependent on membership levels than in Britain. Moreover, my results support the argument that union competition has different effects on strike incidence across different contexts. I found substantial cross-national differences in the strength and nature of the multi-unionism/strike relationship. This relationship was sometimes positive, sometimes negative, and sometimes nonexistent. At the company-level, however, I had no information on how various unions are organized; the ECS-2009 data provide information only on the number of unions at the workplace, and not whether disparate unions have a distinct occupational, political, or religious basis. For future research, this again raises the question about the mechanisms by which multi-unionism is associated with strike activity, and whether different explanations apply in different contexts (Akkerman 2008).

Finally, I determined the extent to which a country's trade union system influences the company-level effects of union organization on strike incidence. My findings confirm that micro-level labor relationships and their outcomes should be studied within their macro-level contexts. I showed that the level of union density in a country, the number of union confederations and the degree of union decentralization directly affect the likelihood of industrial action in individual companies. This implies that after accounting for company-specific characteristics of union organization and other firm-level variables, a company is more likely to experience a strike when it is established in a country with high membership rates, more confederations, and a decentralized union movement.

Through cross-level interactions I was able to show that a country's degree of union decentralization influences the firm-level association between union organization and strikes. Generally, I found that the company-level effects of union organization on strikes are weaker in countries where the union movement is more decentralized. In decentralized systems, workplace branches have greater autonomy to launch a strike and will therefore be less reliant on organizational resources and constraints. The same might apply to countries with high union density. Firm-level resources like workscouncil domination, or constraints like interunion competition, are less strongly associated with strikes when national membership rates are high. Interestingly, a strong union at the local employee representative body may even mitigate potential conflict in case of high national membership levels, and in case the labor movement is highly decentralized. What is also clear from the analysis is that the number of union confederations in a country did not interact with any of the company-level union organization variables. Although strikes are more likely in countries with multiple confederations, the number of confederations did not moderate the effects of firm-level union organization on strikes. 
Using a multilevel analysis of international, firm-level data, I demonstrated that the magnitude and nature of the relationship between union organizations and workplace strikes depends on the labor movement context within a country. A few reservations apply with regard to this article. Although organizational resources help to explain the capacity for strike mobilization, a focus on resources provides little information on the sources of labor conflict. Resource mobilization theory may be criticized for disregarding the relationship between variation in workplace grievances and strike incidence, implicitly assuming a "constancy of discontent" (cf. McAdam, McCarthy, and Zald 1988: 697). To even better understand the conditions under which resources matter, future research may expand the models presented here by acknowledging the variation in workplace grievances. Next, the large-scale analyses presented here come at the cost of detail with regard to the country-specific features of bargaining systems or economic conditions. Subsequent studies might more thoroughly address the differences in union or federation structures across nations. Next, other country-level characteristics might affect labor relationships and collective action at the level of individual firms. For example, Brandl and Traxler (2010) summarized an extensive list of potential economic and institutional factors that shape the opportunity and constraints for industrial conflict. Moreover, contexts can change. This study, which used data for 2009, is a snapshot of European companies during an economic crisis. Longitudinal data would be required to determine whether time-varying conditions influence the results presented here. I leave it to future research to address these issues. In doing so, the methodological approach taken in this article, despite its limitations, is promising. 


\section{Appendix A}

Table A.1. Descriptive Statistics of the Company-Level Variables

\begin{tabular}{|c|c|c|c|c|}
\hline Variables & Mean & $\begin{array}{l}\text { Standard } \\
\text { deviation }\end{array}$ & Minimum & Maximum \\
\hline Strike incidence & 0.12 & 0.33 & 0.00 & 1.00 \\
\hline Union membership & 0.00 & 0.63 & -2.21 & 1.70 \\
\hline Multi-unionism & 0.00 & 0.45 & -1.38 & 1.78 \\
\hline Union-dominated works council & 0.00 & 0.43 & -0.96 & 0.76 \\
\hline \multicolumn{5}{|l|}{ Economic activity } \\
\hline C-D-E & 0.32 & 0.47 & 0.00 & 1.00 \\
\hline NACE F & 0.06 & 0.24 & 0.00 & 1.00 \\
\hline NACE G & 0.10 & 0.29 & 0.00 & 1.00 \\
\hline NACE H & 0.02 & 0.13 & 0.00 & 1.00 \\
\hline NACE I & 0.04 & 0.20 & 0.00 & 1.00 \\
\hline NACE J & 0.02 & 0.15 & 0.00 & 1.00 \\
\hline NACE $\mathrm{K}$ & 0.07 & 0.25 & 0.00 & 1.00 \\
\hline NACE L & 0.12 & 0.32 & 0.00 & 1.00 \\
\hline NACE M & 0.10 & 0.30 & 0.00 & 1.00 \\
\hline NACE N & 0.11 & 0.31 & 0.00 & 1.00 \\
\hline NACE O & 0.05 & 0.22 & 0.00 & 1.00 \\
\hline \multicolumn{5}{|l|}{ Company size } \\
\hline 10-19 employees & 0.11 & 0.31 & 0.00 & 1.00 \\
\hline 20-49 employees & 0.20 & 0.40 & 0.00 & 1.00 \\
\hline 50-99 employees & 0.19 & 0.39 & 0.00 & 1.00 \\
\hline 100-199 employees & 0.14 & 0.34 & 0.00 & 1.00 \\
\hline 200-399 employees & 0.16 & 0.37 & 0.00 & 1.00 \\
\hline 400-500 employees & 0.05 & 0.22 & 0.00 & 1.00 \\
\hline $500+$ employees & 0.15 & 0.36 & 0.00 & 1.00 \\
\hline Public sector & 0.37 & 0.48 & 0.00 & 1.00 \\
\hline \multicolumn{5}{|l|}{ Company status } \\
\hline Independent & 0.62 & 0.49 & 0.00 & 1.00 \\
\hline Subsidiary site & 0.18 & 0.39 & 0.00 & 1.00 \\
\hline Headquarters & 0.18 & 0.39 & 0.00 & 1.00 \\
\hline Unknown & 0.01 & 0.09 & 0.00 & 1.00 \\
\hline \multicolumn{5}{|l|}{ Level of collective agreement } \\
\hline No collective agreement & 0.14 & 0.34 & 0.00 & 1.00 \\
\hline Company level & 0.32 & 0.47 & 0.00 & 1.00 \\
\hline Higher level & 0.45 & 0.50 & 0.00 & 1.00 \\
\hline Mixed & 0.08 & 0.27 & 0.00 & 1.00 \\
\hline
\end{tabular}

Source: ECS-2009.

Note: $N=5,873$. 
Table A.2. Descriptive Statistics of the Country-Level Variables

\begin{tabular}{lccc}
\hline Country & Union density & Number of confederations & Union decentralization \\
\hline Austria & 29.08 & 1.00 & 1.00 \\
Belgium & 51.87 & 3.00 & 3.00 \\
Bulgaria & 20.09 & 3.00 & 4.00 \\
Cyprus & 54.30 & 4.00 & 4.00 \\
Czech Republic & 17.42 & 4.00 & 5.00 \\
Denmark & 67.61 & 4.00 & 2.00 \\
Estonia & 7.27 & 2.00 & 5.00 \\
Finland & 67.52 & 3.00 & 2.00 \\
France & 7.63 & 7.00 & 5.00 \\
Germany & 19.12 & 3.00 & 0.00 \\
Greece & 23.97 & 2.00 & 5.00 \\
Hungary & 16.81 & 6.00 & 4.50 \\
Ireland & 35.20 & 1.00 & 5.00 \\
Italy & 33.43 & 7.00 & 3.00 \\
Latvia & 14.80 & 1.00 & 6.00 \\
Lithuania & 8.47 & 3.00 & 6.00 \\
Luxembourg & 37.33 & 4.00 & 2.00 \\
Malta & 51.22 & 3.00 & 7.00 \\
Netherlands & 19.04 & 3.00 & 0.00 \\
Poland & 15.60 & 3.00 & 5.00 \\
Portugal & 20.49 & 4.00 & 4.00 \\
Romania & 32.83 & 5.00 & 4.00 \\
Slovakia & 17.17 & 2.00 & 5.00 \\
Slovenia & 29.66 & 7.00 & 4.00 \\
Spain & 15.01 & 6.00 & 4.00 \\
Sweden & 68.77 & 3.00 & 0.00 \\
United Kingdom & 27.63 & 1.00 & 5.00 \\
\hline & & & \\
\hline
\end{tabular}

Source: Visser (2011).

\section{References}

Akkerman, Agnes. 2000. Verdeelde Vakbeweging en Stakingen: Concurrentie om Leden (Divided labor movement and strikes: Competition for members) [Thesis]. Amsterdam: Thela. 2008. Union competition and strikes: The need for analysis at the sector level. Industrial and Labor Relations Review 61(4): 445-59.

Baayen, R. Harald. 2011. Package "Language R.” R package version 1.4.

Bates, Doug, Martin Maechler, and Ben Bolker. 2011. Package "Ime4." Linear mixed-effects models using S4 classes. R package version 0.999375-42.

Benson, John, and Howard Gospel. 2008. The emergent enterprise union? A conceptual and comparative analysis. International Journal of Human Resource Management 19(7): 1365-82.

Blanchflower, David, and John Cubbin. 1986. Strike propensities at the British workplace. Oxford Bulletin of Economics and Statistics 48(1): 19-39.

Brandl, Bernd, and Franz Traxler. 2010. Labour conflicts: A cross-national analysis of economic and institutional determinants, 1971-2002. European Sociological Review 26(5): 51940 .

Campolieti, Michael, Robert Hebdon, and Douglas Hyatt. 2005. Strike incidence and strike duration: Some new evidence from Ontario. Industrial and Labor Relations Review 58(4): 610-30.

Carley, Mark, Annalisa Baradel, and Christian Welz. 2005. Works Councils: Workplace Representation and Participation Structures. Eurofound Report No. ef04143. Dublin: European Foundation.

Clegg, Hugh A. 1976. Trade Unionism under Collective Bargaining: A Theory Based on Comparisons of Six Countries. London: Basil Blackwell. 
Coutrot, Thomas. 1998. How do institutional frameworks affect industrial relations outcomes? A micro-statistical comparison of France and Britain. European Journal of Industrial Relations 4(2): 177-205.

Dobson, John R. 1997. The effects of multi-unionism: A survey of large manufacturing establishments. British Journal of Industrial Relations 35(4): 547-66.

Drago, Robert, and Mark Wooden. 1990. The determinants of strikes in Australia. Journal of Industrial Relations 32(1): 32-52.

Edwards, Paul K. 1978. Time series regression models of strike activity: A reconsideration with American data. British Journal of Industrial Relations 16(3): 320-34.

Enders, Craig K., and Davood Tofighi. 2007. Centering predictor variables in cross-sectional multilevel models: A new look at an old issue. Psychological Methods 12(2): 121-38.

Eurofound and TNS Infratest. 2010. European Foundation for the Improvement of Living and Working Conditions and TNS Infratest Sozialforschung Munich. 2010. European Company Survey, 2009 [computer file]. Colchester, Essex: UK Data Archive [distributor], October 2010. SN: 6568 .

Franzosi, Roberto. 1989. One hundred years of strike statistics: Methodological and theoretical issues in quantitative strike research. Industrial and Labor Relations Review 42(3): 348-62.

- 1995. The Puzzle of Strikes. Class and State Strategies in Postwar Italy. New York: Cambridge University Press.

Gelman, Andrew, and Jennifer Hill. 2007. Data Analysis Using Regression and Multilevel/Hierarchical Models. Cambridge: Cambridge University Press.

Gramm, Cynthia L. 1986. The determinants of strike incidence and severity. A micro-level study. Industrial and Labor Relations Review 39(3): 361-76.

Gumbrell-McCormick, Rebecca, and Richard Hyman. 2010. Works councils: The European model of industrial democracy? In Adrian Wilkinson, Paul J. Gollan, Mick Marchington, and David Lewin (Eds.), The Oxford Handbook of Participation in Organizations, pp. 286-314. Oxford: Oxford University Press.

Hancké, Bob. 1993. Trade union membership in Europe, 1960-1990: Rediscovering local unions. British Journal of Industrial Relations 31 (4): 593-613.

Harcourt, Mark, and Helen Lam. 2011. Inter-union conflict in a multi-union, non-exclusive bargaining regime: New Zealand lessons for the United States. Conference Paper. Labor and Employment Relations Association Series. 63rd Annual Meeting.

Hofmann, David A., and Mark B. Gavin. 1998. Centering decisions in hierarchical linear models: Implications for research in organizations. Journal of Management 24(5): 623-41.

Hox, Joop J. 2010. Multilevel Analysis: Techniques and Applications, 2nd ed. New York: Routlegde.

Ingram, Peter, David Metcalf, and Jonathan Wadsworth. 1993. Strike incidence in British manufacturing in the 1980s. Industrial and Labor Relations Review 46(4): 704-17.

Katz, Harry C. 1993. The decentralization of collective bargaining: A literature review and comparative analysis. Industrial and Labor Relations Review 47 (1): 3-22.

Kastellec, Jonathan, and Eduardo Leoni. 2007. Using graphs instead of tables in political science. Perspectives on Politics 5(4): 755-71.

Kaufman, Bruce E. 1982. The determinants of strikes in the United States, 1900-1977. Industrial and Labor Relations Review 35(4): 473-90.

Kelly, John. 1996. Union militancy and social partnership. In Peter Ackers, Chris Smith, and Paul Smith (Eds.), The New Workplace and Trade Unionism, pp. 77-109. London: Routlegde.

Korpi, Walter, and Michael Shalev. 1979. Strikes, industrial relations and class conflict in capitalist societies. British Journal of Sociology 30(2): 164-87.

Machin, Stephen, Mark Stewart, and John Van Reenen. 1993. The economic effects of multiple unionism: Evidence from the 1984 Workplace Industrial Relations Survey. Scandinavian Journal of Economics 95(3): 279-96.

McAdam, Doug, John D. McCarthy, and Mayer N. Zald. 1988. Social movements. In Neil J. Smelser (Ed.), Handbook of Sociology, pp. 695-738. Newbury Park, CA: Sage.

Oswald, Andrew J. 1979. Wage determination in an economy with many trade unions. Oxford Economic Papers 31(3): 369-85.

Piazza, James A. 2005. Globalizing quiescence: Globalization, union density and strikes in 15 industrialized countries. Economic and Industrial Democracy 26(2): 289-314. 
Riedmann, Arnold. 2009. European Company Survey. Technical Report: Methodology, Questionnaire Development and Fieldwork. Munich: TNS Infratest Sozialforschung.

Ross, Arthur M., and Paul Hartman. 1960. Changing Patterns of Industrial Conflict. New York and London: John Wiley \& Sons.

Ross, Arthur M., and Donald Irwin. 1951. Strike experience in five countries, 1927-1947: An interpretation. Industrial and Labor Relations Review 4(3): 323-42.

Shalev, Michael. 1992. The resurgence of labour quiescence. In Marino Regini (Ed.), The Future of Labour Movements, pp. 102-132. London: Sage.

Shorter, Edward, and Charles Tilly. 1974. Strikes in France, 1830-1968. Cambridge: Cambridge University Press.

Snyder, David. 1975. Institutional setting and industrial conflict: Comparative analyses of France, Italy and the United States. American Sociological Review 40(3): 259-78.

Supiot, Alain. 2001. Beyond Employment: Changes in Work and the Future of Labour Law in Europe. Oxford: Oxford University Press

Traxler, Franz, Sabine Blaschke, and Bernhard Kittel. 2001. National Labour Relations in International Markets: A Comparative Study of Institutions, Change, and Performance. Oxford: Oxford University Press.

Tsebelis, George, and Peter Lange. 1995. Strikes around the world: A game theoretic approach. In Sanford M. Jacoby (Ed.), The Workers of Nations: Industrial Relations in a Global Economy, pp. 101-25. New York: Oxford University Press.

Visser, Jelle. 1995. The Netherlands: From paternalism to representation. In Joel Rogers and Wolfgang Streeck (Eds.), Works Councils. Consultation, Representation, and Cooperation in Industrial Relations, pp. 79-114. Chicago: University of Chicago Press.

2011. The ICTWSS Database: Database on Institutional Characteristics of Trade Unions, Wage Setting, State Intervention and Social Pacts in 34 Countries Between 1960 and 2007. Version 3 [computer file]. Amsterdam: Amsterdam Institute for Advanced Labour Studies, University of Amsterdam, May.

Welz, Christian, and Timo Kauppinen. 2004. Social Dialogue and Conflict Resolution in the Acceding Countries. Dublin: European Foundation for the Improvement of Living and Working Conditions.

Wheeler, Hoyt N. 1984. Determinants of strikes: Comment. Industrial and Labor Relations Review 37(2): 263-69.

Whitfield, Keith, Paul Marginson, and William Brown. 1994. Workplace industrial relations under different regulatory systems: A survey-based comparison of Australia and Britain. British Journal of Industrial Relations 32(3): 319-38. 
Copyright of Industrial \& Labor Relations Review is the property of Cornell University and its content may not be copied or emailed to multiple sites or posted to a listserv without the copyright holder's express written permission. However, users may print, download, or email articles for individual use. 